\title{
Evaluation of Serodiagnosis for Differentiating Serogroups of Agrobacterium tumefaciens Biovar 3*
}

\author{
Hiroyuki SAWADA**, Jun IMADA** and Hiroyuki IEKI**
}

\begin{abstract}
Key words : Agrobacterium tumefaciens, biovar 3, serogroup, slide agglutination test, serodiagnosis.
\end{abstract}

Recently, the incidence of grapevine crown gall disease caused by Agrobacterium tumefaciens biovar 3 has increased in Japan ${ }^{7}$. Propagation materials contaminated with the pathogen may be associated with the spread of the disease to new plantings ${ }^{5}$. It is, therefore, important to develop simple and convenient methods such as serodiagnosis for epidemiological studies and for indexing of propagation materials. In our previous report ${ }^{9)}$, we examined the serological relationships among biovar 3 strains by using polyclonal antisera prepared against these strains for the development of serodiagnosis and demonstrated that the strains used could be separated into 4 serogroups (A-D) based on the differences of somatic antigens (heat-stable antigens). These serogroup-specific antisera and suitable serological techniques may be adaptable for epidemiological studies and indexing of grapevine. However, further work is needed to develop a practical method of serodiagnosis, by estimating the suitability and convenience of various serological techniques.

In this paper, the applications of the enzyme-linked immunosorbent assay (ELISA) and slide agglutination test (SAT) for serodiagnosis were evaluated, and SAT was demonstrated to be the optimum method for the differentiation of biovar 3 serogroups.

Five polyclonal antisera" ${ }^{9}$, which were prepared against G-Ag-27 (serogroup A), G-Ag-26 (B), G-Ag-60 (C), NCPPB 2562 (D) and G-Ag-19 (not grouped), were used. Twenty strains of biovar 3 (including 2 overseas strains, NCPPB 2562 and NCPPB 1771) used in the present experiment are listed in Table 1. Strains other than those of biovar 3 were the same as those used in our previous experiment ${ }^{9)}$.

Antigens for ELISA were prepared by suspending 24-hour-old cultures growing on PPGA ${ }^{7)}$ slants at $28^{\circ} \mathrm{C}$ into sodium carbonate buffer at a concentration of $c a .10^{8} \mathrm{cfu} / \mathrm{ml}$. A $100 \mu \mathrm{l}$ aliquot of antigens added to each well of a microtiter plate was dried by incubating the plate overnight in a $37^{\circ} \mathrm{C}$ circulating air incubator. Dried plates were incubated with $200 \mu$ l of fixative ${ }^{3)}$ (25\% ethanol, $10 \%$ acetic acid) per well for $15 \mathrm{~min}$ at room temperature. After washing with PBS-Tween, alkaline phosphataseconjugated antibodies ( $100 \mu \mathrm{l}$ per well) were added and incubated for $3 \mathrm{hr}$ at $37^{\circ} \mathrm{C}$. After washing, a 200 $\mu 1$ aliquot of enzyme substrate $(1 \mathrm{mg} / \mathrm{ml}$ of $p$-nitrophenyl phosphate in $10 \%$ diethanolamine) was added to each well and incubated for $120 \mathrm{~min}$ at room temperature. Absorbance in each well was measured at $410 \mathrm{~nm}$ with a Dynatech Microelisa Minireader MR590.

The reactivity of the biovar 3 strains in ELISA was investigated by using enzyme-conjugated G-Ag-27 (serogroup A) specific antibodies at a 1,600-fold dilution with PBS-Tween. As shown in Table 2 , all the biovar 3 strains reacted strongly with a $A_{410}$ value more than 2.00 after 120 min incubation, and therefore, the serogroups could not be distinguished. In contrast, Alarcon $e t$ al. ${ }^{1}$ reported differences in ELISA reactions among biovar 3 strains using polyclonal antisera. Moreover, the antiserum against G-Ag-27 gave a specific reaction to the serogroup-A strains in both agglutination and Ouchterlony double diffusion tests ${ }^{9}$. These facts suggest that the differences in reactivity of the biovar 3 strains depend on the antisera, the serological techniques and the concentration of antigens and antisera used.

${ }^{*}$ Contribution No. E-145 of the Fruit Tree Research Station 果樹試験場業績番号：E-145

** Akitsu Branch, Fruit Tree Research Station, Ministry of Agriculture, Forestry and Fisheries, Akitsu, Hiroshima 729-24, Japan

農林水産省果樹試験場安芸津支場 
Table 1. Strains of Agrobacterium tumefaciens biovar 3 used in the present experiment

\begin{tabular}{cl}
\hline \hline Serogroup $^{\text {a) }}$ & \multicolumn{1}{c}{ Strain $^{\text {b) }}$} \\
\hline A & YGAt 32-3 \\
& G-Ag-4, 27, 39, 45, 52, 62 \\
& K-Ag-1, 2 \\
& NCPPB 1771 \\
B & G-Ag-21, 23, 26, 46, 48, 61, 66 \\
C & G-Ag-60 \\
D & NCPPB 2562 \\
(not grouped) & G-Ag-19 \\
\hline
\end{tabular}

a) See our previous report ${ }^{9}$.

b) For the assignment of strains to taxa and their origin, see our previous reports ${ }^{7,8)}$

Table 2. Reactions of agrobacteria to antiserum prepared against G-Ag-27 (A. tumefaciens biovar 3, serogroup $\mathrm{A}$ ) in enzyme-linked immunosorbent assay

\begin{tabular}{lcc}
\hline \hline Taxon & $\begin{array}{c}\text { Number } \\
\text { of } \\
\text { strains }^{\mathrm{a})}\end{array}$ & $A_{410 \mathrm{~nm}}{ }^{\mathrm{b})}$ \\
\hline Biovar 1 & & \\
A. tumefaciens & 5 & $0.22-0.94$ \\
A. rhizogenes & 4 & $0.47-0.83$ \\
A. radiobacter & 3 & $0.23,1.21,1.78$ \\
Biovar 2 & & \\
A. tumefaciens & 2 & $0.23,0.42$ \\
A. rhizogenes & 1 & 0.45 \\
A. radiobacter & 1 & 0.31 \\
Biovar 3 & & \\
A. tumefaciens & 10 & $>2.00$ \\
$\quad$ serogroup A & 7 & $>2.00$ \\
$\quad$ serogroup B & 1 & $>2.00$ \\
$\quad$ serogroup C & 1 & $>2.00$ \\
$\quad$ serogroup D & 1 & $1.87,1.93$ \\
G-Ag-19 & 2 & $0.21-0.98$ \\
A. rubi & & 0.15 \\
Unclassified & 7 & \\
A. tumefaciens & & \\
Control (carbonate buffer) & & \\
\hline
\end{tabular}

a) See Table 1 (biovar 3) and Sawada and Ieki ${ }^{9)}$ (the others).

b) Absorbance value at $410 \mathrm{~nm}$ was the average of 4 replications.

c) See our previous report ${ }^{9)}$.

The uniform reaction of the biovar 3 strains in ELISA obtained here (Table 2) suggests that a somatic antigen common to all the biovar 3 strains used ${ }^{9}$ may have reacted so strongly that it masked the differences among the serogroups of the strains.

The sensitivity of ELISA was examined, using enzyme-conjugated antibodies specific to G-Ag-27 at various dilutions with PBS-Tween. The use of a 400 -fold-diluted conjugate allowed detection of approximately $10^{4}-10^{5} \mathrm{cfu} /$ well of the homologous strain $\left[A_{410}=0.97\right.$ at $10^{5} \mathrm{cfu} /$ well, $A_{410}=0.51$ at $10^{4}$ $\mathrm{cfu} /$ well, vs. $A_{410}=0.36$ for the control (carbonate buffer)]. Bishop et al. ${ }^{3)}$ performed ELISA using a monoclonal antibody prepared against biovar 3 and detected as few as $2.3 \times 10^{4}$ cells/well, concluding that success in direct ELISA testing of symptomless contaminated grapevines was not to be expected due to the small number of pathogen cells (below the estimated sensitivity) present in the samples. Because the threshold value obtained in the present experiment $\left(10^{4}-10^{5} \mathrm{cfu} /\right.$ well $)$ is about the same as 
Table 3. Reactions of biovar 3 strains to antisera prepared against serogroups A-D in slide agglutination test

\begin{tabular}{|c|c|c|c|c|c|c|c|}
\hline \multirow[b]{2}{*}{ Serogroup ${ }^{a)}$} & \multirow{2}{*}{$\begin{array}{c}\text { Number } \\
\text { of } \\
\text { strains }^{\text {b) }}\end{array}$} & \multicolumn{6}{|c|}{ Antiserum $^{c)}$ to heat-treated cells of } \\
\hline & & $\begin{array}{l}\text { G-Ag-27 } \\
(A)^{d)}\end{array}$ & & $\begin{array}{c}\text { G-Ag-26 } \\
\text { (B) }\end{array}$ & $\begin{array}{l}\text { G-Ag-60 } \\
\text { (C) }\end{array}$ & $\begin{array}{c}\text { NCPPB } 2562 \\
\text { (D) }\end{array}$ & $\begin{array}{c}\text { G-Ag-19 } \\
\text { (not grouped) }\end{array}$ \\
\hline $\mathrm{A}$ & 10 & $+)_{-}+^{w}$ & & - & - & - & - \\
\hline $\mathrm{B}$ & 7 & $-{ }^{f)}$ & & + & $-\mathrm{f})$ & - & $-8)$ \\
\hline $\mathrm{C}$ & 1 & - & ${ }^{6}$ & - & + & - & - \\
\hline $\mathrm{D}$ & 1 & - & & - & - & + & - \\
\hline (G-Ag-19) & 1 & + & & + & + & + & + \\
\hline
\end{tabular}

a) See our previous report ${ }^{9)}$.

b) See Table 1 .

c) Diluted 20 -fold with saline.

d) Serogroup to which the strain belongs.

e) + : massive agglutination within $30 \mathrm{sec}$; $+^{\text {w: }}$ weak agglutination within $2 \mathrm{~min}$; - : no agglutination within $2 \mathrm{~min}$.

f) G-Ag-48, g) G-Ag-26, and 48 gave faint agglutination (observation with a stereomicroscope).

that obtained by Bishop et $a l^{3}{ }^{3)}$, it will be necessary to isolate the pathogens from symptomless grapevines and prepare their dense suspensions as antigens prior to the performance of ELISA.

However, since ELISA as a method for serological identification of bacteria isolated from samples is too complicated to be used routinely, the application of the slide agglutination test (SAT), which is the simplest serological technique, was evaluated. A drop of 20 -fold-diluted antiserum with saline was placed on a microscope slide, to which a small amount of a 24-hour-old culture growing on a PPGA ${ }^{7)}$ slant was added with a needle. The slide was rocked gently along its long axis to mix the antigen and antiserum until agglutination was recorded after $2 \mathrm{~min}$.

With SAT, strains other than those of biovar 3 gave no visible agglutination against 5 antisera used (data not shown). As for the biovar 3 strains, the same serogroup-specific reactions (Table 3) were observed as those obtained in both agglutination and Ouchterlony double diffusion tests ${ }^{9}$, except for G-Ag-19. Namely, 10 strains of serogroup A showed agglutination only in combination with the antiserum against G-Ag-27 (serogroup A), while strains belonging to serogroups $B, C$ and D reacted only with the antisera prepared against G-Ag-26 (serogroup B), G-Ag-60 (C) and NCPPB 2562 (D), respective1y. Thus, it was demonstrated that SAT could be used for rapid identification of biovar 3 strains and differentiation of serogroups.

Besides SAT, immunofluorescence staining is widely used as a serodiagnostic test. Although indirect immunofluorescence staining was tested by using polyclonal antisera against biovar 3 strains and similar differences in the reaction among the strains to our results were observed ${ }^{1,2,4,6)}$, this technique is rather complicated. Furthermore, Bazzi et al. ${ }^{2}{ }^{2}$ and Bishop et al ${ }^{3)}$ reported that fluorescence of biovar 3 strains was very weak in indirect immunofluorescence staining using a monoclonal antibody. In contrast, SAT with serogroup-specific antisera allowed clear differentiation of biovar 3 serogroups (Table 3) and is simpler and more convenient to perform. Thus, SAT will provide a practical method for epidemiological studies and for indexing of grapevines, if it is combined with appropriate methods for the isolation of the pathogens from samples.

\section{Literature cited}

1. Alarcon, B., Lopez, M.M., Cambra, M. and Ortiz, J. (1987). Comparative study of Agrobacterium biotypes 1, 2 and 3 by electrophoresis and serological methods. J. appl. Bacteriol. 62: 295-308.

2. Bazzi, C., Minardi, P., Burr, T.J., Katz, B.H., Bishop, A.L. and Blanchard, L.M. (1988). Monoclonal and polyclonal antibodies in a comparative serological study of Agrobacterium Conn. biovars. Phytopath. medit. $27: 51-56$.

3. Bishop, A.L., Burr, T.J., Mittak, V.L. and Katz, B.H. (1989). A monoclonal antibody specific to Agrobacterium tumefaciens biovar 3 and its utilization for indexing grapevine propagation material. Phytopathology 
79 : 995-998.

4. Bouzar, H. and Moore, L.W. (1987). Complementary methodologies to identify specific Agrobacterium strains. Appl. Environ. Microbiol. 53 : 2660-2665.

5. Burr, T.J. (1988). Crown Gall. In Compendium of Grape Diseases (Pearson, R.C. and Goheen, A.C. eds.). APS Press, St. Paul. pp. 41-42.

6. Miller, H. J. and Vruggink, H. (1981). An assessment of biochemical and serological tests for Agrobacterium radiobacter subsp. tumefaciens. Phytopath. Z. 102 : 292-300.

7. Sawada, H., Ieki, H. and Takikawa, Y. (1990). Identification of grapevine crown gall bacteria isolated in Japan. Ann. Phytopath. Soc. Japan 56 : 199-206.

8. Sawada, H. and Ieki, H. (1992). Phenotypic characteristics of the genus Agrobacterium. Ann. Phytopath. Soc. Japan $58: 37-45$.

9. Sawada, H., Imada, J. and Ieki, H. (1992). Serogroups of Agrobacterium tumefaciens biovar 3 determined using somatic antigens. Ann. Phytopath. Soc. Japan 58: 52-57.

\section{和 文 摘 要}

\section{澤田宏之・今田 準・家城洋之：Agrobacterium tumefaciens biovar 3 の血清群識別法の検討}

Agrobacterium tumefaciens biovar 3 の各血清群（A〜D）に対して作製した抗血清を, ELISA あるいはスライド 凝集反応と組み合わせ，反応特異性について検討した。ELISA では biovar 3 の全菌株が陽性を示したが，検出限界は $10^{4} \sim 10^{5} \mathrm{cfu} /$ well であった。スライド凝集反応の場合, biovar 3 以外の菌株はまったく凝集を示さなかった。一方, biovar 3 では血清群ごとに特異的な反応が認められた。すなわち，血清群 $\mathrm{A}, \mathrm{B}, \mathrm{C}$ および D の各菌株は，同じ血清群 の抗血清に対してのみ肉眼的に認められる凝集を示したことから, 本法が biovar 3 の簡易同定や血清群の識別に利用 できることが明らかになった。 